\title{
EROSION CONTROL WITH GEOTEXTILES MANUFACTURED FROM NATURAL FIBERS IN THE MARGIN OF SÃO FRANCISCO RIVER
}

\author{
Cátia dos Santos Fontes \\ Universidade Federal de Sergipe-UFS, Programa de Pós-graduação em Geografia, São Cristóvão-SE, \\ Brasil \\ catiafiav@hotmail.com
}

Francisco Sandro Rodrigues Holanda

Universidade Federal de Sergipe-UFS, Departamento de Engenharia Agronômica, São Cristóvão-SE,

Brasil

fholanda@infonet.com.br

Renisson Neponuceno de Araujo Filho

Universidade Federal do Tocantins-UFT, Campus Universitário de Gurupi, Gurupi-TO - Brasil nepoaraujo@gmail.com

Luiz Diego Vidal Santos

Universidade Federal de Sergipe-UFS. Programa de Pós-graduação em Ciências da Propriedade Intelectual, São Cristóvão-SE, Brasil vidal.center@academico.ufs.br

Janisson Bispo Lino

Universidade Estadual do Norte Fluminense Darcy Ribeiro-UENF, Campos dos Goytacazes-RJ, Brasil janissonlino@gmail.com

Marks Melo Moura

Universidade Federal do Paraná-UFPR, Programa de Pós-Graduação em Engenharia Ambiental, Curitiba-PR,

\begin{abstract}
Soil erosion is one of the major environmental degradation events in many areas of the world. The Lower São Francisco river has been impacted by changes in the river flow caused by public policies implemented in the recent decades and caused by the electric power plants. From this perspective, it has been tested some sustainable techniques to mitigate the soil loss by controlling bank erosion. The objective of this work was to evaluate the use of geotextiles made from natural fibers on the erosion control in the Lower São Francisco riverbank. The experimental trial was conducted for 12 months monitoring, taking into consideration two periods analysis: rainy and dry, in a riverbank of $16.6^{\circ}$ performing an area of $12.4 \times 4 \mathrm{~m}$, in three blocks with the following treatments:Typha latifolia Geotextile (TG), Juncus sp. Geotextile (JG), Syagrus coronata Geotextile (SG) and Bare Soil (BS) without geotextiles, located on the right bank of the Lower São Francisco river downward, in the municipality of Amparo de São Francisco in Sergipe state, northeastern Brazil. The vegetation cover development, tensile strength, deformation and sediments loss by runoff were evaluated. Among the tested geotextiles, the Syagrus coronata and Juncus sp geotexteis were more efficient in the erosion control producing a less amount of sediment, although on the resistance and durability of the fibers, Typha latifolia presented better results.
\end{abstract}

Keywords: Typha latifolia. Juncus sp.. Syagrus coronata. Soil Bioengineering.

\section{CONTROLE DE EROSÃO COM GEOTEXTIL CONFECCIONADO A PARTIR DE FIBRAS NATURAIS NA MARGEM DO RIO SÃO FRANCISCO}

\section{RESUMO}

Problemas com a erosão do solo são considerados um dos principais eventos de degradação ambiental em muitas áreas do mundo. O baixo curso do rio São Francisco foi impactado por mudanças no seu fluxo causadas por políticas públicas implementadas nas últimas décadas para a geração de energia elétrica. Nesta perspectiva, foram testadas algumas técnicas sustentáveis para mitigar a perda de solo, controlando a erosão no talude do rio. O objetivo deste trabalho foi avaliar o uso de geotêxteis fabricados a partir de fibras naturais no controle da erosão na margem do rio São Francisco. O experimento foi conduzido por 12 meses,

$\begin{array}{lllll}\text { Caminhos de Geografia } & \text { Uberlândia } & \text { v. 22, n. } 84 & \text { dez/2021 } & \text { p. 25-35 Página } 25\end{array}$


considerando a análise de dois períodos: chuvoso e seco, no talude do rio com inclinação de $16,6^{\circ}$, perfazendo uma área de $12,4 \times 4 \mathrm{~m}$, em três blocos, com os seguintes tratamentos: geotêxtil de Typha latifolia (TG), geotêxtil de Juncus sp., geotêxtil (JG), geotêxtil de Syagrus coronata (SG) e solo sem geotêxtil (SG), localizado na margem direita do baixo São Francisco, no município de Amparo de São Francisco, estado de Sergipe, nordeste do Brasil. Foram avaliados o desenvolvimento da cobertura vegetal, resistência à tração, deformação e perda de sedimentos pelo escoamento. Entre os geotêxteis testados, os geotêxteis de Syagrus coronata e Juncus sp foram os mais eficientes no controle da erosão, produzindo menor quantidade de sedimentos, embora na resistência e durabilidade das fibras, Typha latifolia apresentou melhores resultados.

Keywords: Typha latifólia. Juncus sp.. Syagrus coronata. Bioengenharia de Solos.

\section{INTRODUCTION}

A watershed, by its dynamics, as a planning unit, clearly represents the anthropic action in the use of soil and water, exemplified by erosion processes. Integrating knowledge of geomorphology with soil bioengineering, through works on erosion control techniques, is important to identify solutions to mitigate the environmental impacts (REY et al., 2019). Erosion is an expression of degradation in the riverbanks causing soil loss associated to environmental impacts, requiring studies that present solutions through mitigation techniques, environmentally and technically sustainable, and mainly with low cost (JANSSEN et al., 2019).

The fluvial dynamics of São Francisco river, especially after the flow regularization due to the dam construction, has caused environmental impacts that reflect on the bank erosion in the Lower São Francisco (ROCHA et al., 2018; MACHADO et al., 2018). The change in the dynamics of the São Francisco river channel, which is reflected in the acceleration of erosion processes, has stimulated studies that work with sustainable techniques recovering the biodiversity of the severely affected riparian vegetation (HOLANDA et al., 2007, 209). Soil bioengineering, which combines elements of traditional engineering with living materials or inert materials such as geotextiles, has proven to be a viable alternative considering costs and environmental sustainability.

Facing the erosive processes, natural fiber geotextiles play an efficient role as part of soil bioengineering technique to control erosions in riverbanks, as it reduces sediment loss, favoring soil water infiltration, providing vegetation development and adding organic matter to the soil by natural degradation (MANIVANNAN et al., 2018).

The studies performed by Guerra et al. (2015) proved the efficiency in the use of Mauritia flexuosa geotextiles, an native species in South America, in the comparison of exposed soil, showing that there was a loss of $255.85 \mathrm{~g} \mathrm{~m}^{-2}$ of sediment in the geotextile plot, while in the non-geotextile plot it reached $4,390.96 \mathrm{~g} \mathrm{~m}^{-2}, 17$ times higher, assessed over a five-month period with a rainfall of 2,067.50 $\mathrm{mm}$ of rainfall. Land cover prevents the direct impact of rainfall on the soil, thus decreasing the chances of erosion, and promotes increases in the above and the below ground biological diversity and in longterm benefits (FEKETE et al., 2016).

In the analysis of total sediment loss, the soil properties, amount of organic matter, soil texture and erosivity of the region should be considered (NSIAH and SCHAAF, 2019)

The geotextiles are intended to ensure soil cover avoiding the direct action of erosive agents and reducing evaporative water loss, allowing an easier plant development (GIUPPONI et al., 2019). Resistance to degradation of fibers tends to decrease with the increasing exposure time. Natural fibers are degradable materials, generally applied as geotextiles with the desired decomposition and the effect after the vegetation can assume the function of soil reinforcement (PRAMBAUER et al., 2019). As reported by Urashima et al. (2020), the field degradation of two geotextiles after 62 days of exposure, presented a reduction of $12.98 \%$ and $19.00 \%$ in their resistance, showing degradation by climatic conditions.

The objective of this work was to evaluate the use of geotextiles made from natural fibers on the erosion control in the Lower São Francisco riverbank.

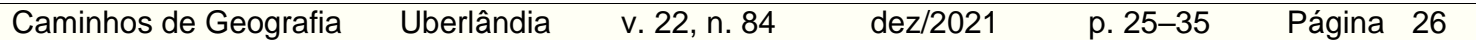




\section{MATERIALS AND METHODS}

\section{Study Area}

The selected site is in an area occupied by the soil classified as Fluvic Entisol (SOIL SURVEY STAFF, 2014), and located on the right bank of the Lower São Francisco River downward, in the municipality of Amparo de São Francisco in Sergipe state, northeastern Brazil. The region's climate is warm, semihumid, with an average annual temperature of $25^{\circ} \mathrm{C}$, and a rainy season in the fall-winter period, from March to September with a rainfall of 800 to $1,300 \mathrm{~mm}$ (ARAÚJO FILHO et al., 2017).

\section{Soil Bioengineering Technique - The use of geotextiles}

Geotextile was manufactured from fibers of Typha latifolia, Linn., Juncus sp. and Syagrus coronata and tested in the field, located in the right bank of the São Francisco River, and then submitted to laboratory analysis through collected samples in the field.

Typha latifolia L. is a rhizomatous species that forms dense stands in many continental aquatic ecosystems in Brazil as part of the genus of monocotyledonous, rhizomatous plants, which groups about 30 species of the Typhaceae family. It is a dominant species in aquatic macrophyte communities, typical of swamps, measuring about two meters, presenting coffee-colored ears in the breeding season, containing many seeds that are dispersed by the wind (BÁEZ-LIZARAZO, 2018). Syagrus coronata (Martius.) Beccari is representative of the Arecaceae family, currently gathering 115 genera and 1500 species. It is a palm typical of the semi-arid northeastern area, then the species has a clear preference for dry and arid regions of the Brazilian bioma, the so called "Caatinga" (RUFINO et. al., 2008). It measures from $8 \mathrm{~m}$ to $11 \mathrm{~m}$, with leaves of about $3 \mathrm{~m}$ in length, pinnated with long petiole, and its dark green leaflets are arranged in several planes. Juncus sp. it is a group of plants like grasses that grow in swamps, and constitutes a single family. These plants have cylindrical stems with three rows of leaves, and their small flowers are greenish or brown, rich in cellulose. Juncus is propagated by clump division, since they are rhizomatous plants that have short nodes in their rhizomes (ROESSING; PETRY, 2009).

The experimental trial was conducted during 12 months monitoring, taking into consideration an analysis in two periods: rainy and dry in a river slope of $16.6^{\circ}$ performing an area of $12.4 \mathrm{X} 4 \mathrm{~m}$, in three blocks with the following treatments: Typha Geotextile (TG), Juncus Geotextile (JG), Syagrus Geotextile (SG) and Bare Soil (BS) without geotextiles such as a blank plot. To install the treatments in the field, positions were drawn in each block to randomize them, with three repetitions for each one as shown in the sketch (Figure 1). In each randomized block, sediment collectors made with plastic bags were placed to analyze the following parameters: sediment loss, soil texture and organic matter content.

Figure 1 - Sketch of the experimental area with three blocks and different experimental treatments: TG - Typha Geotextile; JG - Juncus Geotextile; SG - Syagrus Geotextile and BS - Bare Soil (without geotextile).

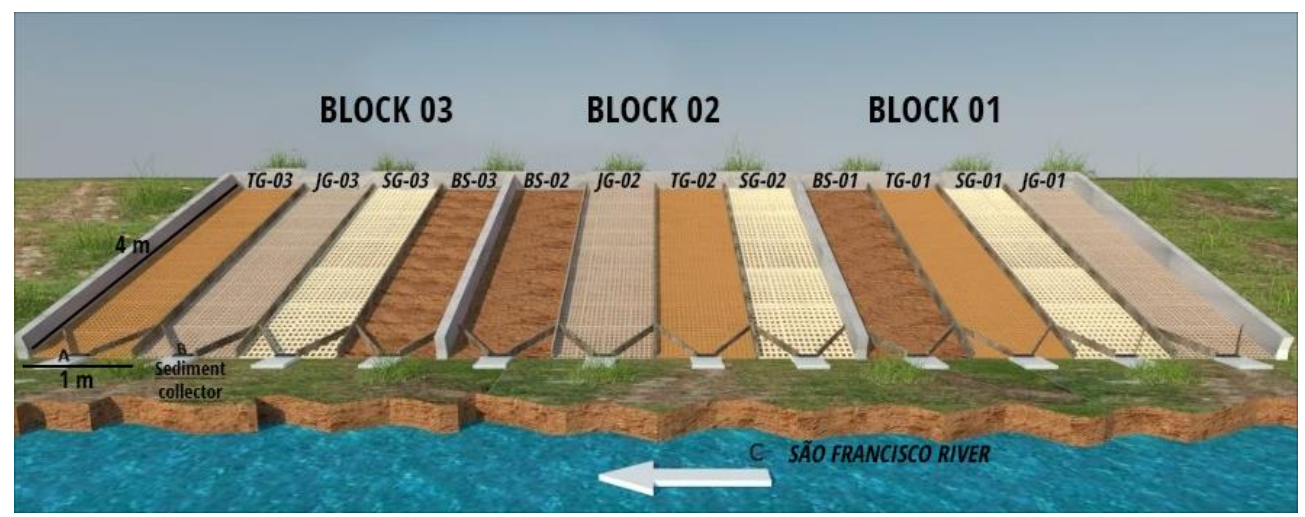

After choosing the experimental area, the geotextiles were with iron clamps (Figure 2). According to Kumar and Das (2018), the fixation of geotextiles with staples brings resistance against the water runoff.

Figure 2 - Installation of the geotextile's treatments in the Experimental area in the riverbank.

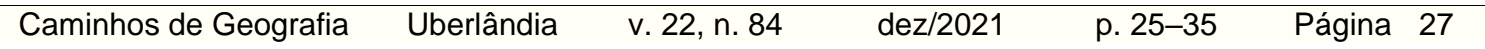



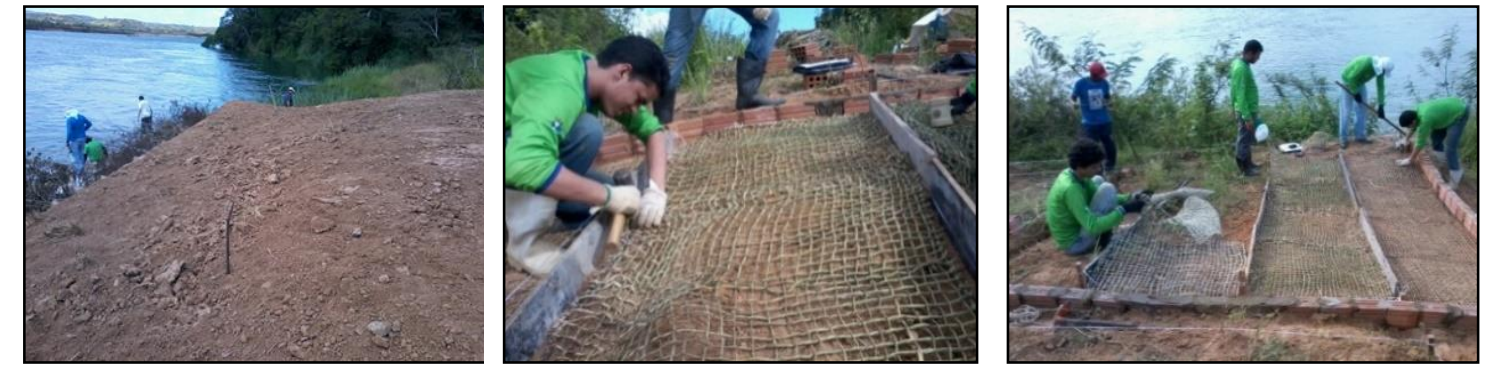

\section{Geotextiles degradation and vegetation cover monitoring}

A natural geotextile degradation was performed under environmental conditions (solar radiation, wind, rainfall and vegetation etc). Samples were collected considering four levels of degradation: lintact geotextile (T0), field exposure for 60 days (T1), field exposure for 90 days (T2), field exposure for 120 days (T3) and field exposure for 180 days (T4). The geotextile samples presented the dimensions of 20 $\mathrm{cm}$ long $\times 30 \mathrm{~cm}$ wide. As monitoring degradation went on the vegetation cover development was also monitored. During this period photographic records were carried out to follow the vegetation development in the field during the use of fiber geotextiles.

\section{Tensile strength of natural fibers}

The geotextile samples after collected in the field were taken to the laboratory and placed in the heater at $60^{\circ} \mathrm{C}$ for $24 \mathrm{~h}$ and then stored in a dry and ventilated place, to perform mechanical tensile strength and deformation tests.

Through the tensile test, the resistance to which each sample was submitted and its displacement until rupture was obtained. The tensile force at the moment of rupture of each sample was obtained, and the displacement to rupture and the material deformation was determined by Equation 1:

$$
\varepsilon=\frac{\Delta L}{L 0} * 100
$$

Where:

$-\varepsilon=$ Strain (\%);

$-\Delta \mathrm{L}=$ Sample length variation $(\mathrm{mm})$;

- $L_{0}=$ Sample initial length $(\mathrm{mm})$.

\section{Sediment loss by surface runoff}

At the slope toe, sediment collection gutters were installed (Figure 3), to collect the sediments from the runoff provided by the rainfall during the period from June to December. For the determination of the total weight of the sediments carried in the plots, the filtering method was used (SURGUIO, 1973). Sediments were collected every time a rain was recorded (Figure 03), performing a total of 11 collections.

Figure 3 - View of the gutters used to collect sediment in the plots.
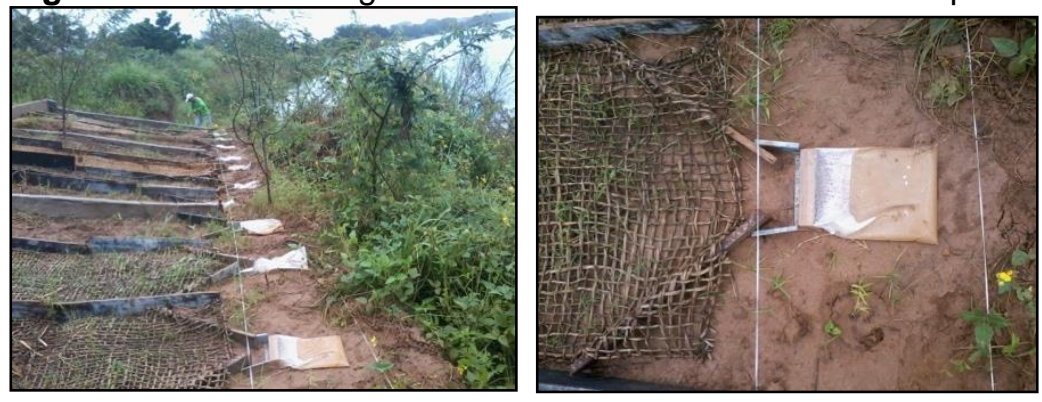
Figure 6 - Vegetation cover of the treatments TG - Typha Geotextile; JG - Juncus Geotextile; SG Syagrus Geotextile and BS - Bare Soil (without geotextile) 90 days after the implementation, in the Block 3.
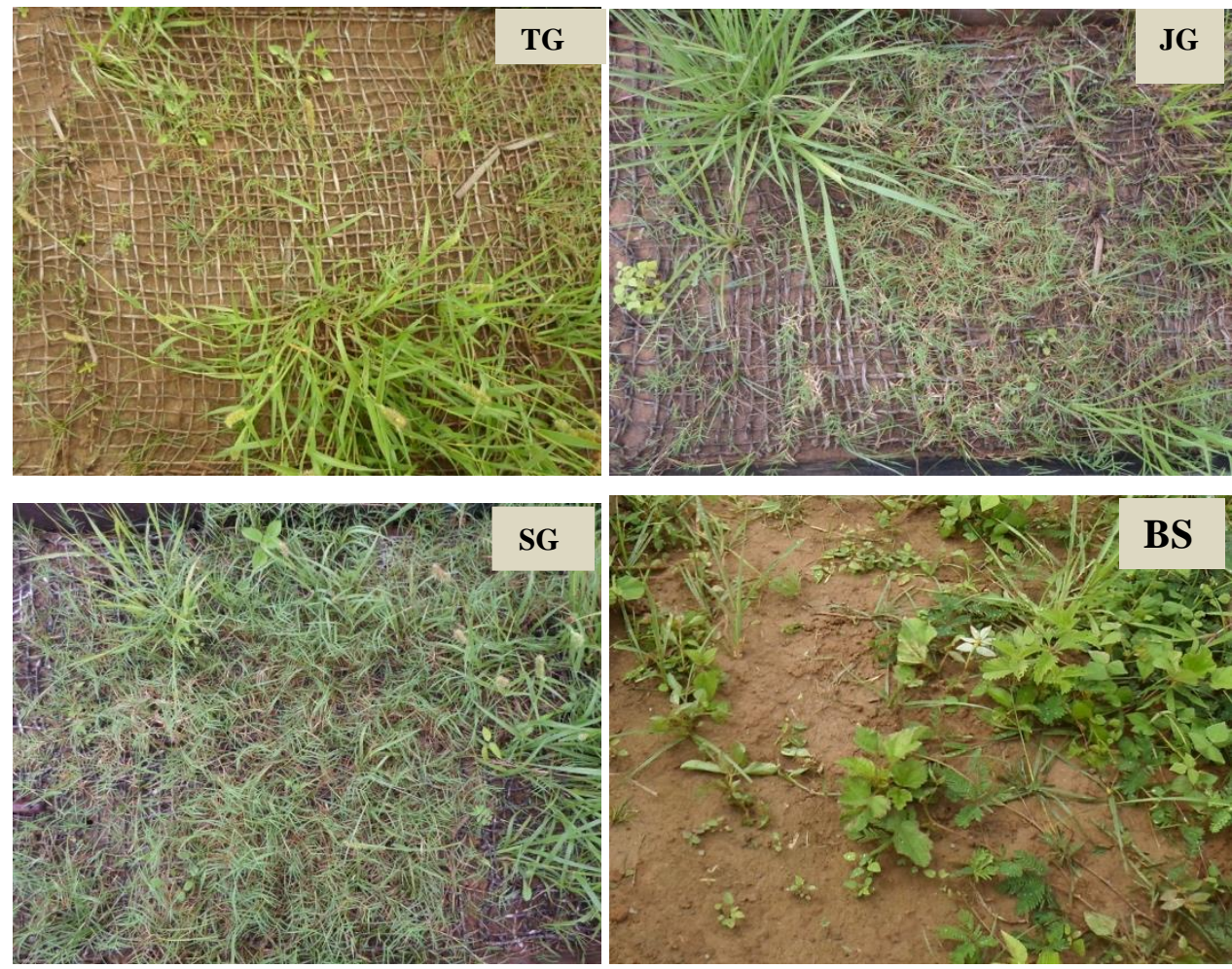

The use of geotextiles on riverbanks favored the runoff control, providing better water infiltration in the soil, in addition to retaining more efficiently the soil particles that could be carried with the soil without vegetation cover.

\section{Sediment loss by surface runoff}

When assessing sediment production, one of the main erosion agents of runoff should be considered the rain. Considering that the experiment was implemented to evaluate a rainy and a dry season, it was possible to analyze the variations of precipitation and sediment loss in the different treatments at different times. Eleven sediment samplings were performed from the gutters at the end of each plot, always at the highest recorded peaks of rainfall, then it was possible to relate rainfall and sediment transported by runoff. According to Guerra et al. (2015), the use of geotextiles as a soil bioengineering technique play this important role slowing runoff velocities, trapping sediments and controlling erosion.

All treatments using geotextiles showed lower sediment losses compared to the BS treatment (Figure 7). These results show that the geotextiles allowed the protection of the soil, resulting in retention of part of the sediments transported on the slope surface, highlighting the JG and SG treatments, in agreement with Whitman et al. (2019), who mentioned that sediment retention using geotextile well-executed natural barriers can retain at least $90 \%$ of the expected sediments loss. 
Cátia dos Santos Fontes

Francisco S. R. Holanda

Erosion control with geotextiles manufactured from natural fibers in the margin of São Francisco River

Renisson N. de Araujo Filho

Luiz Diego Vidal Santos Janisson Bispo Lino Marks Melo Moura

Figure 7 - Monthly variation of precipitation and sediment loss in the treatments: TG - Typha Geotextile; JG - Juncus Geotextile; SG - Syagrus Geotextile and BS - Bare Soil (without geotextile).
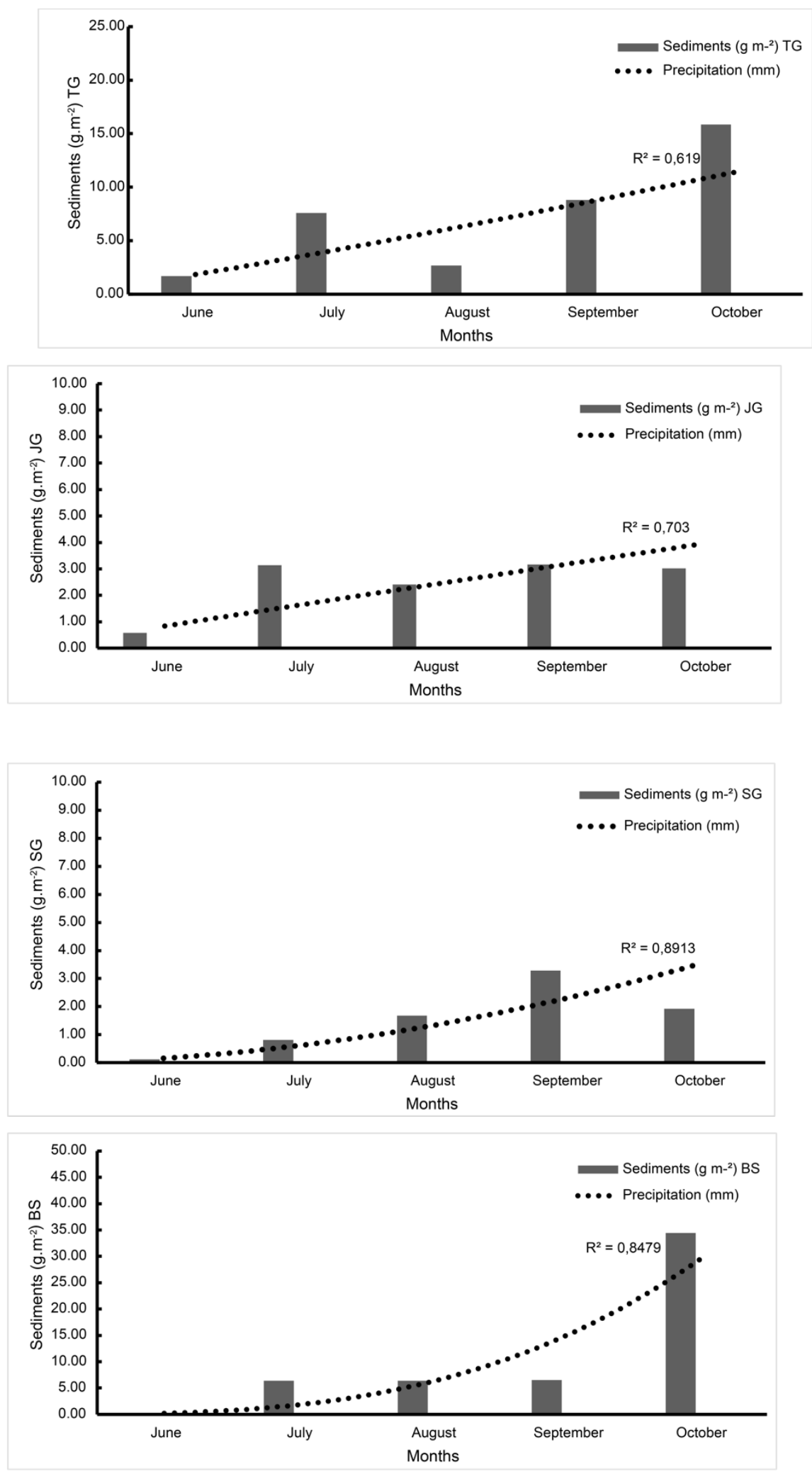
It was observed in the field that the lower value of sediment loss in the SG (Syagrus geotextile) treatment compared to the other geotextiles, is justified by the best vegetation cover (Figure 6). This protection promoted by vegetation, as a physical barrier, prevented soil disaggregation, allowing better water infiltration and sediment retention, avoiding or decreasing surface runoff. In general, vegetation cover intercepts the rainfall and decreases the occurrence of splash erosion due to different vegetation morphologies and structures, being able to control the soil erosion (FENG et al., 2018).

Although the Typha Geotextile (TG) retains less sediment in the early stages of collection, it has been shown to be much more resilient over the months, allowing a longer lasting soil protection of the slope, creating better chances for the erosion control.

The occurrence of rainfall in the experimental area directly influenced the sediment transport results. Especially in the BS treatment, where there was a greater loss of sediments caused by low infiltration generating a greater runoff and consequently, greater sediment transport.

In the plots with geotextiles, it was observed a higher absorption of moisture, with greater infiltration, serving as obstacles to surface runoff and reducing the sediment transport. In this process, the importance of the development of vegetation cover is emphasized, reinforcing the soil protection, greater infiltration through the roots and reducing the transport of particles on the soil surface (MARQUES et al., 2016).

The results presented in this research have brought the importance of applying soil bioengineering techniques in the control of slope erosion, and the unprotected soils are more susceptible to erosion, especially rainfall, associated with soil morphology and structure (FENG et al., 2018).

\section{CONCLUSIONS}

Typha geotextile showed the best results in tensile strength tests, even after natural degradation in the field, when compared to Juncus Geotextile and Syagrus geotextile, mainly because it lasts along the whole monitored time, under the environment conditions, allowing the vegetation cover development to protec the riverbank. Syagrus and Juncus geotextiles are more efficient in the sediment retention, even though these geotextiles are more easily degraded in the field.

Even though the Typha geotextile treatment produces the highest load of sediment among the other treatments, except Bare soil plot, it seems to be much more resilient over the months, allowing for longer lasting soil protection of the slope, creating better chances for the erosion control. On the other hand, the absorption of water by Juncus Geotextile and Syagrus geotextile over time is a problem, since the lasting moisture allows a bigger microbial manifestation that degrades them in a shorter time and makes them more fragile and less lasting in the field over the months

The use of biodegradable geotextiles from the species Typha latifolia. Linn, Juncus sp and Syagrus coronata provided soil protection, favoring the development of vegetation cover, and minimizing the action of erosive agents on the slope, becoming an alternative as a soil bioengineering technique.

\section{REFERENCES}

ARAÚJO FILHO, R. N., HOLANDA, F. S. R., PEDROTTI, A., OLIVEIRA SANTOS, T., ROCHA, I. P. Influência dos Atributos Físicos-Mecânicos do Solo $\mathrm{Na}$ Estabilidade do Talude do Baixo São Francisco. Scientia agraria, v. 18, n. 4, p. 107-113, 2017.

ARTIDTEANG, S.; TANCHAISAWAT, T.; BERGADO D.T. Chaiyaput Natural Fibers in Reinforcement and Erosion Control Applications with Limited Life Geosynthetics . I. Ground Improvement Case Histories. Compaction, Grouting and Geosynthetics. p 717-740, 2015.

BÁEZ-LIZARAZO, M. R.; SANTORO, F. R.; ALBUQUERQUE, U. P.; RITTER, M. R. Aquatic vascular plants as handicraft: a case study in southern Brazil. Acta Botanica Brasilica v.32, n.1, p. 88-98, 2018.

BASU, G.; ROY, A. N.; SANYAL, P.; MITRA, K.; MISHRA, L.; GHOSH, S. K. Bioengineering of river earth embankment using natural fibre-based composite-structured geotextiles. Geotextiles and Geomembranes, v. 47, p 493-501, 2019. 
FEKETE, I.; VARGA, C.; BIRÓ, B.; TÓTH, J. A.; VÁRBÍRÓ, G.; LAJTHA, K.; SZABÓ, G.; KOTROCZÓ, $Z$. The effects of litter production and litter depth on soil microclimate in a central european deciduous forest. Plant and Soil, v. 398, n. (1-2), p. 291 - 300, 2016.

FENG, Y.; CHEN, S.; CHENG, Y. Frank. Stearic acid modified zinc nano-coatings with superhydrophobicity and enhanced antifouling performance. Surface and Coatings Technology, v. 340, p. 55-65, 2018.

GIUPPONI, L., BORGONOVO, G., GIORGI, A., BISCHETTI, G. B. How to renew soil bioengineering for slope stabilization: some proposals. Landscape and ecological engineering, v. 15, n. 1, p. 37-50, 2019.

GUERRA, A. J. T.; BEZERRA, J. F. R.; FULLEN, M. A.; MENDONÇA, J. K. S.; JORGE, M. C. O. The effects of biological geotextiles on gully stabilization in São Luís, Brazil. Natural Hazards, v. 75, p 2625-2636, 2015.

HOLANDA, F.S.R.; SANTOS, C. M. S; CASADO, A. P. B; BANDEIRA, A. A.; ROCHA, I. P; ARAÚJO FILHO, R. N.; GÓIS, S. S; VIEIRA, T. R.S. Análise multitemporal e caracterização dos processos erosivos no Baixo São Francisco sergipano. Revista Brasileira de Geomorfologia, v. 8, n. 2, p. 8796, 2007.

HOLANDA, F. S. R.; BANDEIRA, A. A.; RO CHA, I. P.; ARAÚJO FILHO, R. N; RIBEIRO, L. F.; ENNES, M. A. Controle da erosão em margens de cursos d'água: das soluções empíricas à técnica da bioengenharia de solos. Ra'ega O Espaço Geográfico em Análise, 17, p.93-101, 2009.

INMET - Instituto Nacional De Meteorologia. Disponível em:

<http://www.inmet.gov.br/portal/index.php?r=bdmep/bdmep>. Acesso em 01 Jul. 2020.

IBM Corp, R. 2017. IBM SPSS Statistics for Macintosh, Version 25.0. Armonk, NY: IBM, 2017(Released 2017).

JANSSEN, P.; CAVAILLÉ, P.; BRAY, F.; EVETTE, A. Soil bioengineering techniques enhance riparian habitat quality and multi-taxonomic diversity in the foothills of the Alps and Jura Mountains. Ecological engineering, v. 133, p. 1-9, 2019.

KUMAR, N.; DAS D. Nonwoven geotextiles from nettle and poly (lactic acid) fibers for slope stabilization using bioengineering approach. Geotextiles and Geomembranes, v. 46, p. 206-213, 2018.

MACHADO, L.; HOLANDA, F. S. R.; PEDROTTI, A.; FERREIRA, O. J. M.; ARAÚJO FILHO, R. N.; MOURA, M. M. Efeito de Raízes de Vetiver Sobre a Resistência a Penetração de Um Neossolo Flúvico nas Margens do Rio São Francisco. Revista Caatinga, v. 31, n. 4, p. 935-943, 2018.

MANIVANNAN, S.; KHOLA, O. P. S.; KANNAN, K.; CHOUDHURY, P. K.; THILAGAM, V. K. Efficacy of open weave jute geotextiles in controlling soil erosion and its impact on hill slope stabilization.

Indian Journal of Agricultural Sciences, v. 88, n. 5, p. 679-84, 2018.

MARQUES, A.R.; VIANNA C.R.; MONTEIRO, M. L.; PIRES, B.O.S.; URASHIMA, D.C.; PONTES, P. $P$. Utilizing coir geotextile with grass and legume on soil of Cerrado, Brazil: An alternative strategy in improving the input of nutrients in degraded pasture soil? Applied Soil Ecology, v. 107, p 290-29, 2016.

NSIAH, P. K.; SCHAAF, W. The potentials of biological geotextiles in erosion and sediment control during gold mine reclamation in Ghana. Journal of Soils and Sediments, v. 19, n. 4, p. 1995-2006, 2019.

PRAMBAUER, M.; WENDELERB C.; WEITZENBÖCKA J.; BURGSTALLERA C. Biodegradable geotextiles - An overview of existing and potential materials. Geotextiles and Geomembranes, v. 47, p 48-59, 2019.

REY, F.; BIFULCO, C.; BISCHETTI, G. B.; BOURRIER, F.; CESARE, G.; FLORINETH, F.; PEKLO, K. Soil and water bioengineering: Practice and research needs for reconciling natural hazard control and ecological restoration. Science of the total environment, v. 648, p. 1210-1218, 2019.

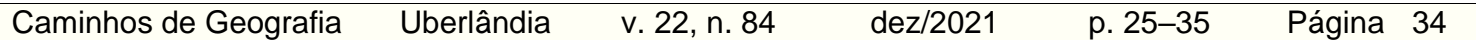


ROCHA, I. P.; HOLANDA, F. S. R.; ROLIM, M. M.; LINO, J. B.; ARAÚJO FILHO, R. N. Magnitude and Spatiotemporal Variation of the Erosion on the Slope of the Lower São Francisco River, Northeastern Brazil. Journal of Experimental Agriculture International, v.24, n.1, p. 1-11, 2018.

RUFINO, M. U. de L; COSTA, J. T. de M; SILVA, V. A. da; ANDRADE, L. de H. C. Conhecimento e uso do ouricuri (Syagrus coronata) e do babaçu (Orbignya phalerata) em Buíque, PE, Brasil. Acta Botanica Brasilica, v. 22, n.4, p.1141-1149, 2008.

ROESSING, M; PETRY, C. A água e o junco nos jardins aquáticos antigos e contemporâneos. Revista Brasileira de Horticultura Ornamental, v.15, n.1, p.63-70, 2009.

SOIL SURVEY STAFF. Keys to Soil Taxonomy. A Basic system of soil classification for making and interpreting soil surveys. Agriculture Handbook Number 436, 12th Ed. National Resources Conservation Services. 2014

SHIRAZI, M. G.; RASHID, A. S. A.; NAZIR, R. B.; RASHID, A. H. A.; KASSIM, A.; HORPIBULSUK, S. Investigation of tensile strength on alkaline treated and untreated kenaf geotextile under dry and wet conditions. Geotextiles and Geomembranes, v. 47, n. 4, p. 522-529, 2019.

SURGUIO, K. Introdução à sedimentologia. São Paulo, Edgard Blucher. Ed. a Universidade de São Paulo, 1973.

URASHIMA, B. M. C.; URASHIMA, D. C.; CASTRO, C. A. C.; GUIMARÃES, M. G. A. Degradação de Geotêxteis Expostos às Intempéries/Degradation of Geotextiles Exposed to Weather. Brazilian Journal of Development, v. 6, n. 5, p. 25208-25219, 2020.

WHITMAN, J. B.; ZECH, W. C.; DONALD, W.N. Full-Scale Performance Evaluations of Innovative and Manufactured Sediment Barrier Practices. Transportation Research Record, v. 2673, n. 8, p. 284297, 2019.

ZHU, H.; ZHANG, L. M. Field investigation of erosion resistance of common grass species for soil bioengineering in Hong Kong. Acta Geotechnica, v. 11, n. 5, p. 1047-1059, 2016. 